\title{
GUAVIRA EMERGENCE AND SEEDLING PRODUCTION WITH SUBSTRATES CONTAINING ORGANIC COMPOST AND SOIL UNDER DIFFERENT SCREEN ENVIRONMENTS ${ }^{1}$
}

\author{
EDILSON COSTA ${ }^{2}$, PRISCILLA NÁTALY DE LIMA SILVA ${ }^{3}$, \\ MARÇAL HENRIQUE AMICI JORGE ${ }^{4}$ ANTONIO FLÁVIO ARRUDA FERREIRA ${ }^{3}$
}

\begin{abstract}
This study aimed to evaluate different proportions of organic compost and soil as a substrate for the guavira emergence and seedling formation under different protected environments, in the high Pantanal region of the state of Mato Grosso do Sul. The seeds were placed in polyethylene bags ( $15 \times 25$ centimeters) filled with four percentages of organic compost $(0 \%, 20 \%, 80 \%$, and $100 \%$ of total volume) mixed with soil. These substrates were tested in agro-nurseries covered with black screen and $50 \%$ thermo-reflecting shade cloths. The substrate with $20 \%$ soil and $80 \%$ organic compost and the black screen shade cloth promote the best performance in the seedling production.

Index terms: Campomanesia adamantium (Camb.) Berg, native fruit, protected environments.

\section{EMERGÊNCIA E FORMAÇÃO DE MUDAS DE GUAVIRA COM SUBSTRATOS CONTENDO COMPOSTO ORGÂNICO E SOLO SOB DIFERENTES AMBIENTES TELADO}

\begin{abstract}
RESUMO- Este estudo teve como objetivo avaliar diferentes proporções de composto orgânico e solo como substrato para a emergência e formação de mudas de guavira, em diferentes ambientes protegidos, na região do alto Pantanal Sul-Mato-Grossense. As sementes foram acondicionadas em sacolas de polietileno de $15,0 \times 25,0 \mathrm{~cm}$ preenchidas com quatro porcentagens de composto orgânico $(0 \% ; 20 \% ; 80 \%$ e $100 \%$ do volume total) misturadas ao solo. Estes substratos foram testados em viveiros agrícolas de tela preta e termorrefletora de $50 \%$ de sombreamento. O substrato $20 \%$ solo e $80 \%$ composto orgânico e o ambiente com tela preta promoveram melhor desempenho na formação das mudas.
\end{abstract}

Termos para indexação: Campomanesia adamantium (Camb.) Berg, frutas nativas, ambientes protegidos.

Guavira belongs to the Campomanesia genus - Myrtaceae family. The origin of the name comes from the tupi-guarani and means bitter bark. The plant is also known as guabiroba, guabirobeira, and gabirobeira (COUTINHO et al., 2010). The plant is rich in vitamin $\mathrm{C}$ and its fruits and leaves are used to treat cold. The fruits are the most used part of the plant, which are consumed in natura and used to produce juice, jam, ice-cream, liquor, candies, and cachaça (VALLILO et al., 2005). Despite being a savanna native plant, guavira is in risk of extinction because of anthropogenic actions such as burns. In addition, there is no preoccupation to replant it. The guavira species is propagated by through sexual and asexual. However, propagation studies are needed (SCALON et al., 2009).
Considering savanna fruit plant cultivation an adequate method for propagation and cultivation are necessary. The seedling production under protected environment allows control against meteorological agents, such as temperature, air humidity, radiation, wind, and frost. For maximum plant performance in these environments, many factors are involved and need to be well chose and utilized, for example, irrigation, substrate and recipient. The use of organic matter in substrates mixed with soil helps to improve the substrate physical characteristics and, as consequence, enhancing the seedling root development. For fruit plant such as passion fruit and papaya, the addition up to $21 \%$ of commercial organic compost mixed with soil produced seedlings with better quality (COSTA et al., 2010a, COSTA et al., 2011).

\footnotetext{
'(Trabalho 133-12).Recebido em: 10-04-2012. Aceito para publicação em: 28-08-2012.

${ }^{2}$ Professor Doutor da Universidade Estadual de Mato Grosso do Sul (UEMS), Unidade de Cassilândia. Rodovia MS 306, Km 6, Zona rural, CEP 79540-000, Cassilândia-MS. E-mail: mestrine@uems.br

${ }^{3}$ Graduandos (as) da UEMS, Bolsistas PIBIC, Unidade de Aquidauana. E-mail: priscilla_nataly@hotmail.com; tonho_flavio@ yahoo.com.br

${ }^{4}$ Pesquisador da Embrapa Pantanal, Corumbá-MS. E-mail: marcal.jorge@embrapa.br
} 
This study aimed to evaluate different proportions of organic compost and soil as a substrate for the guavira [Campomanesia adamantium (Camb.) Berg] emergence and seedling formation under different protected environments from November of 2009 to April of 2010 at the Mato Grosso do Sul State University Unit in Aquidauana, Brazil.

Black dotted polyethylene bags ( $15 \times 25$ centimeters) were used as recipients, filled with substrates containing soil and four percentages of organic compost. The treatments were as following: S1- $100 \%$ soil; S2- $80 \%$ soil $+20 \%$ organic compost; S3- $20 \%$ soil and $80 \%$ organic compost; and S4$100 \%$ organic compost (Table 1). These substrates were tested in two agro-nurseries, covered with black screen shade cloth (A1) and thermo-reflecting shade cloth (A2), both allowing 50\% of light penetration, made with galvanized steel structure, and closure of $45^{\circ}$.

The soil, classified as Red Yellow Argisoil, was obtained in a site within the Aquidauana University Unit from a layer between 10 and 40 centimeters of depth. It was air dried and screened with a $2-\mathrm{mm}$ mesh. The commercial organic compost had as ingredients slaughterhouse waste, sugar cane bagasse, fruits, legumes, cereals, and others. The substrate rested for 15 days, being irrigated once a day for better mineralization. The fruits were harvested in November and, after the seeds extraction, they were dried in a shade area for 24 hours (SCALON et al., 2009). The sowing was done subsequently placing two seeds per recipient, in a 2-cm depth. In the case of emergence of two seedlings, one was removed when they had four true leaves. The irrigation was done manually, twice a day, in the morning and before evening.

In the first day after sowing (DAS), counting of seedling emergence started, to calculate the emergence speed index (ESI). The data were recorded daily until the $25^{\text {th }}$ DAS. The seedling height $(\mathrm{SH})$ was measured using a rule with milimetric scale and stem diameter (SD) using a digital caliper. The SH and SD, aerial part and root dry weight (ADW and RDW, respectively) were measured at 150 DAS. The drying was done using a forced air circulation drier adjusted to $65^{\circ} \mathrm{C}$ for 72 hours. ADW and RDW were sum to obtain the total dry weight (TDW). The Dickson's quality index (DQI), as formula below, and the ratio between ADW and RDW (DWR) were also calculated by DQI $=$ TDW $(\mathrm{g}) /[\mathrm{SH}(\mathrm{g}) / \mathrm{SD}(\mathrm{mm})+$ $\mathrm{ADW}(\mathrm{g}) / \mathrm{RDW}(\mathrm{g})]$.

Each protected environment of the experiment with substrates was carried out in a completely randomized design with six replicates. Initially, the data were individually analyzed for substrates (in each cultivation environment), followed by the evaluation of the residual mean square and all factors together.

For all the variables evaluated in this study, the ratio between the residual mean square (RMSR) of the individual variance analyses of the experiments did not reach $7: 1$, allowing, then, the analyses of all factors together (BANZATTO; KRONKA, 2006). The evaluation of the cultivation environments of guavira seedlings, according to the variance analyses, indicated that the environments did not show significant differences for ESI, SH, ADW, and DWR variables. However, there were differences for SD, RDW, TDW, and DQI. The interactions between the two factors did not show differences for ESI and DWR.

The DWR and the ESI variables did not differ in the cultivation environments. In the substrates, the greater DWR was verified for the substrate composed by $20 \%$ of soil $+80 \%$ of organic compost, and the greater ESI for the substrate composed by $100 \%$ of organic compost (Table 2). Like this, it can be verified that for great percentage of organic matter there were better dry weight distribution between plant parts and faster growth. This greater percentage of organic matter can be aggregating better physical structure to the substrate and nutrient availability. According to Lima et al. (2006), the organic matter played an important role as nutrient resource. The microbial process are stimulated and, also, better physical and chemical characteristics are conferred (porosity, aeration, water retention, etc.). The substrates with greater concentration of organic matter and having high total porosity provided a satisfactory water retention capacity and aeration, producing more vigorous seedlings.

The DWR is an index that, in accordance with Cruz et al. (2006), expresses the seedling quality and this relation must be around 2.0. In this study, the ratio varied between 1.0 and 1.73 , when considering the cultivation environments and substrates (Table 2).

Taking into consideration the evaluation of the environments for the different substrates, it was verified that for substrates containing $100 \%$ of soil and $20 \%$ of soil, the seedlings grown in the black screen presented greater height, diameter, dry weight, and DQI when compared to seedlings grown within the thermo-reflecting screen. It was also observed for SD of seedlings produced with the substrate containing $80 \%$ of soil $+20 \%$ of organic compost, and for the DQI of seedlings when using the $100 \%$ of organic compost (Table 3 ).

For this variable (DQI), the guavira seedlings 
had better performance under the black screen. Probably, the black color could have held more thermal energy in the end of the day when compared to the thermo-reflecting screen, contributing to night temperature conditions be more favorable to plant development. For yellow passion fruit seedlings grown in polyethylene bags, Costa et al. (2009a) observed that the black screen provided taller plants (18.29 $\mathrm{cm})$ than those of the thermo-reflecting screen (15.99 $\mathrm{cm})$. In spite of that, for papaya seedlings grown in the same recipient, Costa et al. (2010c) verified greater height $(27.64 \mathrm{~cm})$ in the thermo-reflecting screen in comparison with those in the black screen $(23.96$ $\mathrm{cm}$ ). Costa et al. (2010b) observed that, for cucumber seedlings, substrates containing soil and coconut fiber provided greater biomass accumulation in the greenhouse and nursery equipped with black screen in relation to thermo-reflecting screen. It can be noted the reciprocal interaction and influence of environments and substrates in the development of various species, where the factors altogether can induce better environmental, physical, and nutritional conditions.

The substrate evaluation within each environment showed that, under the black screen, the seedlings of the substrate containing $80 \%$ of soil + $20 \%$ of organic compost were smaller comparing to those of the other substrates. Under the thermoreflecting screen, the seedlings of this same substrate did not show difference for height measurements for those grown in the $100 \%$ of soil. Although, they were smaller when compared with those of the $100 \%$ of organic compost (Table 3). The results indicated that greater percentages of organic compost mixed with soil favored the guavira seedling growth. It can be explained by the fact that the organic matter released greater nutrient quantities (Table 1) and, like that, provided better soil conditioning. The compost improved the aeration, porosity, water absorbance, nutrient uptake, and microorganisms living conditions.

These results go against those found by Rodrigues et al. (2010) for tomato seedlings, where more vigorous seedlings were obtained with substrates containing smaller percentages $(7 \%)$ of compost when compared to $14 \%$ and $21 \%$. As concluded by Costa et al. (2010a), studying passion fruit seedlings, and Costa et al. (2011), studying papaya, smaller percentages of compost $(7 \%, 14 \%$, and $21 \%)$ provided more vigorous seedlings than those grown in substrates with $28 \%$. Due to its characteristics of proper adaptation and having a great extend of seedling formation, the plant could have been adapted to substrates containing greater amounts of compost. As the seedling stay more time in the nursery it could happen that the organic matter decayed more rapidly and, consequently, could have released more nutrients. However, Santos et al. (2011), working with jatobazeiro-do-cerrado, which is also a rustic fruit, found no effect of this compound in increasing the total biomass of the seedlings at 120 days after sowing.

Under the black screen, the seedlings with greater SD, ADW, and TDW values were observed for the substrates containing $80 \%$ of organic compost $+20 \%$ of soil, with an index that did not differ from substrates with smaller percentages of compost. Under the thermo-reflecting screen, this substrate provided seedlings with equal diameter compared to those of the substrates composed by $100 \%$ of organic compost but greater than those of the others. In addition, the values did not differ for ADW, RDW, TDW, and DQI when comparing seedlings grown in the substrate containing $80 \%$ of soil $+20 \%$ of organic compost and $100 \%$ of organic compost (Table 3 ). It can be noticed that substrates with $80 \%$ of organic compost could be an alternative to produce guavira seedlings. The formation period, $150 \mathrm{DAS}$, provided a satisfactory solubility of the compost organic matter, and nutrients availability to seedlings. Costa et al. (2009b) verified that substrates containing soil, compost, and vermiculite at $1: 1: 1$, prepared 30 days before sowing provided better biomass results for papaya seedlings.

The DQI is a balanced formula where the relations of morphological parameters such as TDW, $\mathrm{ADW}, \mathrm{RDW}, \mathrm{SH}$, and SD are well weight. It represents very well the vigor and robustness of seedling going to the field (CRUZ et al., 2006). Concerning the quality standards, the index seems to be a good indicator of robustness of guavira seedlings, mainly when grown under black screen.

The substrate containing $80 \%$ of organic compost is indicated to produce guavira seedlings; the environment with black screen provides better development and vigor of guavira seedlings. 
TABLE 1- Chemical analyses of substrates used in the guavira experiment. Aquidauana, MS.

\begin{tabular}{|c|c|c|c|c|c|c|c|c|c|c|c|}
\hline & $\underset{* *}{\mathrm{pH}}$ & $\mathrm{Ca}$ & $\begin{array}{c}\mathrm{Mg} \\
\mathrm{mol} / \mathrm{dm}\end{array}$ & $\mathrm{K}$ & $\mathrm{C}_{\mathrm{g} / \mathrm{c}}$ & $\begin{array}{l}\mathrm{OM}^{*} \\
\mathrm{n}^{3}\end{array}$ & $\mathrm{P}$ & $\mathrm{Fe}$ & $\begin{array}{c}\mathrm{Mn} \\
\mathrm{mg} / \mathrm{dm}^{3}\end{array}$ & $\mathrm{Cu}$ & $\mathrm{Zn}$ \\
\hline & 5.30 & 2.52 & 0.70 & 0.12 & 7.82 & 13.45 & 10.9 & 9.0 & 51.85 & 0.06 & 2.32 \\
\hline $\mathrm{S}_{2}$ & 6.70 & 6.1 & 4.22 & 0.9 & 32.98 & 5 & 80 & 86.2 & 17 & 1.3 & 31. \\
\hline S & 6.50 & 15.73 & 11.82 & 3.92 & 128.76 & 22 & 68 & 122.03 & 16 & 3.69 & 26.18 \\
\hline $\mathrm{S} 4$ & 6.70 & 14.87 & 11.91 & 3.92 & 139.78 & 240.42 & 704.80 & 118.72 & 147.87 & 4.02 & 26.19 \\
\hline
\end{tabular}

Source: Solanalise Soil testing Laboratory, Dourados, MS. * $\mathrm{OM}=$ Organic matter; ${ }^{* * S} 1=100 \%$ of soil; $\mathrm{S} 2=80 \%$ of soil $+20 \%$ of organic compost; $\mathrm{S} 3=20 \%$ of soil $+80 \%$ of organic compost; $\mathrm{S} 4=100 \%$ of organic compost.

TABLE 2 - Aerial and root dry weight ratio (DWR) and emergence speed index (ESI) of guavira seedlings. Aquidauana, MS.

\begin{tabular}{lcl}
\hline & DWR & ESI \\
\hline Black screen & $1.30 \mathrm{~A}^{*}$ & $1.03 \mathrm{~A}$ \\
Reflecting screen & $1.25 \mathrm{~A}$ & $1.01 \mathrm{~A}$ \\
$\mathrm{CV}(\%)$ & 19.72 & 47.66 \\
\hline $100 \% \mathrm{~S}$ and $0 \% \mathrm{OC}^{* *}$ & $1.17 \mathrm{~B}$ & $1.01 \mathrm{~B}$ \\
$80 \% \mathrm{~S}$ and $20 \%$ OC & $1.21 \mathrm{~B}$ & $0.76 \mathrm{C}$ \\
$20 \% \mathrm{~S}$ and $80 \%$ OC & $1.73 \mathrm{~A}$ & $1.04 \mathrm{~B}$ \\
$0 \% \mathrm{~S}$ and $100 \%$ OC & $1.00 \mathrm{~B}$ & $1.27 \mathrm{~A}$ \\
$\mathrm{CV}(\%)$ & 22.81 & 15.36 \\
\hline
\end{tabular}

*Values within a column followed by a common uppercase letter do not differ significantly at the 0.05 probability level according to Tukey's test. **S=Soil; OC=Organic compost.

TABLE 3- Environment and substrate interactions for seedling height (SH), stem diameter (SD), aerial dry weight (ADW), root dry weight (RDW), total dry weight (TDW), and Dickson's quality index (DQI) of guavira seedlings at 150 days after sowing (DAS). Aquidauana, MS.

\begin{tabular}{|c|c|c|c|c|}
\hline \multirow[b]{3}{*}{$100 \% \mathrm{~S}$ and $0 \% \mathrm{OC}$} & \multicolumn{4}{|c|}{ Black screen Reflecting screen Black screen Reflecting screen } \\
\hline & \multicolumn{2}{|c|}{$\mathrm{SH}(\mathrm{cm})$} & \multicolumn{2}{|c|}{$\mathrm{SD}(\mathrm{mm})$} \\
\hline & $4.00 \mathrm{Aa}^{*}$ & $2.88 \mathrm{Cb}$ & $1.82 \mathrm{Ba}$ & $1.24 \mathrm{Cb}$ \\
\hline $80 \% \mathrm{~S}$ and $20 \% \mathrm{OC}$ & $2.93 \mathrm{Ba}$ & $3.20 \mathrm{BCa}$ & $1.68 \mathrm{Ca}$ & $1.45 \mathrm{Bb}$ \\
\hline $20 \% \mathrm{~S}$ and $80 \% \mathrm{OC}$ & $4.08 \mathrm{Aa}$ & $3.65 \mathrm{Bb}$ & $1.95 \mathrm{Aa}$ & $1.59 \mathrm{Ab}$ \\
\hline \multirow[t]{2}{*}{$0 \% \mathrm{~S}$ and $100 \% \mathrm{OC}$} & $3.62 \mathrm{Ab}$ & $4.25 \mathrm{Aa}$ & $1.61 \mathrm{Ca}$ & $1.60 \mathrm{Aa}$ \\
\hline & \multicolumn{2}{|c|}{ ADW (g) } & \multicolumn{2}{|c|}{ RDW (g) } \\
\hline $100 \% \mathrm{~S}$ and $0 \% \mathrm{OC}$ & $0.208 \mathrm{Ba}^{*}$ & $0.119 \mathrm{Bb}$ & $0.161 \mathrm{Aa}$ & $0.110 \mathrm{Bb}$ \\
\hline $80 \% \mathrm{~S}$ and $20 \% \mathrm{OC}$ & $0.171 \mathrm{BCa}$ & $0.171 \mathrm{ABa}$ & $0.137 \mathrm{Aa}$ & $0.149 \mathrm{Aa}$ \\
\hline $20 \% \mathrm{~S}$ and $80 \% \mathrm{OC}$ & $0.294 \mathrm{Aa}$ & $0.212 \mathrm{Ab}$ & $0.169 \mathrm{Aa}$ & $0.126 \mathrm{ABb}$ \\
\hline \multirow[t]{2}{*}{$0 \% \mathrm{~S}$ and $100 \% \mathrm{OC}$} & $0.133 \mathrm{Ca}$ & $0.161 \mathrm{ABa}$ & $0.160 \mathrm{Aa}$ & $0.138 \mathrm{ABa}$ \\
\hline & \multicolumn{2}{|c|}{ TDW $(\mathrm{g})$} & \multicolumn{2}{|c|}{ DQI } \\
\hline $100 \% \mathrm{~S}$ and $0 \% \mathrm{OC}$ & $0.370 \mathrm{Ba}$ & $0.229 \mathrm{Bb}$ & $0.106 \mathrm{ABa}$ & $0.065 \mathrm{Bb}$ \\
\hline $80 \% \mathrm{~S}$ and $20 \% \mathrm{OC}$ & $0.308 \mathrm{Ca}$ & $0.320 \mathrm{Aa}$ & $0.104 \mathrm{ABa}$ & $0.095 \mathrm{Aa}$ \\
\hline $20 \% \mathrm{~S}$ and $80 \% \mathrm{OC}$ & $0.463 \mathrm{Aa}$ & $0.338 \mathrm{Ab}$ & $0.121 \mathrm{Aa}$ & $0.085 \mathrm{ABb}$ \\
\hline $0 \% \mathrm{~S}$ and $100 \% \mathrm{OC}$ & $0.293 \mathrm{Ca}$ & $0.299 \mathrm{ABa}$ & $0.096 \mathrm{Ba}$ & $0.079 \mathrm{ABb}$ \\
\hline
\end{tabular}

\footnotetext{
**Values within a column followed by a common uppercase letter, within a line followed by a common lowercase letter do not differ significantly at the 0.05 probability level according to Tukey's test. $* * \mathrm{~S}=$ Soil; $\mathrm{OC}=$ Organic compost.
}

\section{ACKNOWLEDGMENT}

To CNPq by the scholarship (PIBIC/CNPq).

\section{REFERENCES}

BANZATTO,D.A.;KRONKA, S.N.Experimentação agrícola. 4.ed. Jaboticabal: FUNEP, 2006. 237 p.

COSTA, E.; LEAL, P. A. M.; GOMES, V. A.; MACHADO, D.; JARA, M. C. S. Biomassa de mudas de pepinos híbridos conduzidos sob ambientes protegidos. Bragantia, Campinas, v.69, n.2, p.381386,2010 b. 
COSTA, E.; LEAL, P A. M.; GOMES, V. A.; SASSAQUI, A. R. Efeitos do Organosuper ${ }^{\circledR}$ e do ambiente protegido na formação de mudas de mamoeiro. Engenharia Agrícola, Jaboticabal, v. 31, n. 1, p. 41-45, 2011.

COSTA, E.; LEAL, P. A. M.; SANTOS, L. C. R.; VIEIRA, L. C. R. Crescimento de mudas de mamoeiro conduzidas em diferentes ambientes protegidos, recipientes e substratos na região de Aquidauana-MS. Acta Scientiarum. Agronomy, Maringá-PR, v. 32, n. 3, p. 463-470, 2010c.

COSTA, E.; LEAL, P. A. M.; SASSAQUI, A. R.; GOMES, V. A. Doses de composto orgânico comercial na composição de substratos para a produção de mudas de maracujazeiro em diferentes tipos de cultivo protegido. Engenharia Agrícola, Jaboticabal, v. 30, n. 5, p. 776-787, 2010a.

COSTA, E; RODRIGUES, E. T.; ALVES, V. B.; SANTOS, L. C. R.; VIEIRA, L. C. R. Efeitos da ambiência, recipientes e substratos no desenvolvimento de mudas de maracujazeiroamarelo em Aquidauana- MS. Revista Brasileira de Fruticultura, Jaboticabal, v. 31, n. 1, p. 236-244, 2009a.

COSTA, E.; SANTOS, L. C. R.; VIEIRA, L. C. R. Produção de mudas de mamoeiro utilizando diferentes substratos, ambientes de cultivo e recipientes. Engenharia Agrícola, Jaboticabal, v.29, n.4, p.528-537, out./dez. 2009b.

COUTINHO, D. I.; KATAOKA, V. M. F.; HONDA, N. K.; COELHO, R. G.; VIEIRA, M. C.; CARDOSO, C. A. L. Influência da variação sazonal nos teores de flavonoides e atividade antioxidante das folhas de Campomanesia adamantium (Cambess.) O. Berg, Myrtaceae. Revista Brasileira de Farmacognosia, Curitiba, v. 20, n. 3, p. 322-327, 2010.
CRUZ, C. A. F.; PAIVA, H. N.; GUERRERO, C. R. A. Efeito da adubação nitrogenada na produção de mudas de sete-cascas (Samanea inopinata (Harms) Ducke). Revista Árvore, Viçosa, MG, v. 30, n. 4, p. 537-546, 2006.

LIMA, R. L. S.; SEVERINO, L. S; SILVA, M. I. L.; JERÔNIMO, J. F.; VALE, L. S.; BELTRÃO, N. M. E. Substratos para produção de mudas de mamoneira compostos por misturas de cinco fontes de matéria orgânica. Ciência e Agrotecnologia, Lavras, v. 30, n. 3, p. 474-479, 2006.

RODRIGUES, E. T.; LEAL, P. A. M.; COSTA, E.; MESQUITA, V. do A. G. Produção de mudas de tomateiro em diferentes substratos e recipientes em ambiente protegido na região de Aquidauana-MS. Horticultura Brasileira, Brasília, v. 28, n. 4, p. 447-451, 2010.

SANTOS, L. C. R.; COSTA, E.; LEAL, P. A. M.; NARDELLI, E. M. V.; SOUZA, G. S. A. Ambientes protegidos e substratos com doses de composto orgânico comercial e solo na formação de mudas de jatobazeiro em Aquidauana-MS. Engenharia Agrícola, Jaboticabal, v. 31, n. 2, p. 249-259, 2011.

SCALON, S. P. Q.; LIMA, A. A.; SCALON FILHO, H.; VIEIRA, M. C. Germinação de sementes e crescimento inicial de mudas de Campomanesia adamantium Camb.: Efeito da lavagem, temperatura e de bioestimulantes. Revista Brasileira de Sementes, Viçosa,MG, v. 31, n.2, p. 96-103, 2009.

VALLILO, M. I.; GARBELOTTI, M. L.; OLIVEIRA, E.; LAMARDO, L. C. A. Características físicas e químicas dos frutos do cambucizeiro (Campomanesia phaea). Revista Brasileira de Fruticultura, Jaboticabal, v. 27, n. 2, p. 241-244, 2005. 